\title{
Utilization of Spent Broiler Breeder Hen Meat to Develop Value Added Sausages
}

\author{
J. Indumathi ${ }^{1 *}$, M. Shashikumar ${ }^{2}$, G. Vijaya Bhaskar Reddy ${ }^{3}$, \\ A. Jagadeesh Babu ${ }^{4}$ and M. Gnana Prakash ${ }^{5}$ \\ ${ }^{1}$ Department of Livestock Products Technology, N.T.R College of Veterinary Science, \\ Gannavaram, India \\ ${ }^{2}$ Department of Livestock Products Technology, College of Veterinary Science, \\ Hyderabad, India \\ ${ }^{3}$ Department of Livestock Products Technology, College of Veterinary Science, Tirupati, India \\ ${ }^{4}$ Department of Veterinary Public Health, College of Veterinary Science, Tirupati, India \\ ${ }^{5}$ Poultry Research Station, Rajendranagar, Hyderabad, India \\ *Corresponding author
}

\section{A B S T R A C T}

\section{Keywords}

Spent hen, Broiler breeder, Sausages, Chicken, Value addition

\section{Article Info}

Accepted:

07 November 2019

Available Online:

10 December 2019
Meat from spent broiler breeder hens is sold at a lower price because of its poor texture and acceptability when compared to the broilers. The present study was designed for proper utilization of this less expensive meat to produce cheaper and economically viable nutritious value added chicken sausages. Significantly $(\mathrm{P}<0.01)$ higher percent crude protein, total ash, water holding capacity, salt soluble protein extractability, total protein extractability and significantly $(\mathrm{P}<0.01)$ lower percent crude fat and moisture were recorded for spent broiler breeder hen meat when compared to the broiler meat. Spent broiler breeder hen sausages had significantly $(\mathrm{P}<0.05)$ higher cooking yield, emulsion stability, crude protein, crude fat, total ash and lowest $\mathrm{pH}$, cholesterol, penetration value and sensory scores than broiler meat sausages.

\section{Introduction}

Spent broiler breeder hens produce commercial broilers with high hybrid vigor for meat production and these are heavy birds (4 to $6 \mathrm{~kg}$ ) with satisfactory amount of meat in the breast and thighs. Meat from these spent broiler breeder hens is usually tougher and less juicy when compared to broiler meat as it is harvested at the end of the egg laying capacity of the birds. After their production period these spent broiler breeder hens are 
usually slaughtered and used in feed production and also for the production of pet food (Ajuyah et al., 1992; Voller-Reasonover et al., 1997). Sale of spent broiler breeder hens at reasonable prices has become more difficult, affecting producers profits (Kondaiah, 1993). Consumption of meat from spent hens is limited by its poorer sensory quality, in particular poorer tenderness, compared to meat from broilers (Grabowski, 2004; Komiyama et al., 2010 and Lyon et al., 2003). For these reasons, the disposal of spent broiler breeder hens is one of the main economical and environmental problems of the poultry industry (Lyons, 2001). The present study was designed for proper utilization of this less expensive meat to produce cheaper and economically viable nutritious value added chicken sausages. The quality and acceptability of spent broiler breeder hen sausages was assessed in comparison with broiler meat sausages by physico-chemical, microbiological and sensory qualities.

\section{Materials and Methods}

\section{Procurement of raw material and} preparation of ingredients

Spent boiler breeder birds (females) of 72 weeks age and broilers of 6-7 weeks of age were purchased from Chandragiri local market, transported and slaughtered at the Department of Livestock Products Technology, College of Veterinary Science, Tirupati. Slaughter and dressing was performed as per the standard procedure. After chilling overnight, the carcasses were handdeboned and the meat was kept in freezer ($18 \pm 1^{\circ} \mathrm{C}$ ) until further use. For each trial, six birds of each group were taken and such six trials were carried out. The work was designed to prepare sausages using meat from breast, thigh and drumstick of birds from each group. Fresh chicken samples were collected from the thigh and breast muscles of both spent broiler breeder hens and broilers separately after 24 hours of storage at refrigerator temperature $\left(4 \pm 1^{\circ} \mathrm{C}\right)$ and assessed the following physicochemical attributes.

\section{Protein extractability}

Protein extractability was determined according to procedure of Joo et al., (1999). Total proteins (Sarcoplasmic and Myofibrillar) proteins were extracted from $2 \mathrm{~g}$ sample using $40 \mathrm{ml}$ of ice-cold $1.1 \mathrm{M}$ potassium iodide in $0.1 \mathrm{M}$ phosphate buffer $(\mathrm{pH}$ 7.2). The samples were homogenized and kept overnight at $4{ }^{\circ} \mathrm{C}$ with frequent shaking. Samples were centrifuged at $5000 \mathrm{rpm}$ for $20 \mathrm{~min}$ and concentration of protein in the supernatant was determined by the Biuret method.

\section{Protein fractionation}

Protein fractionation was carried out as per the method of Kang and Rice (1970). Sarcoplasamic proteins: $20 \mathrm{~g}$ of meat $+30 \mathrm{ml}$ of chilled distilled water blended in a homogenizer for 2min. Homogenate transferred to volumetric flask and made the volume to $200 \mathrm{ml}$ then kept at $4-5^{\circ} \mathrm{C}$ for overnight and centrifuged at $3000 \mathrm{rpm}$ for 15 minutes. Nitrogen content was measured in the supernatant by micro kjeldhal method.

Myofbrillar protens: Residue from the above experiment was dispended in $200 \mathrm{ml}$ of $0.67 \mathrm{M}$ NACL solution. Kept overnight at $4-5^{\circ} \mathrm{C}$ and centrifuged at $3000 \mathrm{rpm}$ for 15 minutes. Nitrogen content was measured in the supernatant by micro kjeldhal method.

\section{pH}

The $\mathrm{pH}$ of the samples was determined by following the procedure of Jay (1964). Meat sample weighing 25 grams was blended with $100 \mathrm{ml}$ of distilled water for one minute in a 
mechanical blender. From the total homogenate a $50 \mathrm{ml}$ aliquot portion was immediately used for determination of $\mathrm{pH}$ using a digital $\mathrm{pH}$ (Systronics $\mu \mathrm{pH}$ system 361) meter after standardizing the instrument with two standard buffers.

\section{Water holding capacity}

Water holding capacity (WHC) was determined according to Wardlaw et al., (1973). The $20 \mathrm{~g}$ of minced meat sample was placed in a centrifuge tube containing $30 \mathrm{ml}$ $\mathrm{NaCl}(0.6 \mathrm{M})$ and was stirred with glass rod for 1 minute. The tube was then kept at refrigeration temperature $\left(4 \pm 1{ }^{0} \mathrm{C}\right)$ for $15 \mathrm{~min}$, stirred again and centrifuged at $3000 \mathrm{rpm}$ using refrigerated centrifuge (model) for 15 min. The supernatant was measured and amount of water retained by sample were expressed as WHC in percentage.

\section{Proximate composition}

The per cent moisture, crude protein, crude fat and crude fibre were estimated as per the procedures outlined by AOAC (1994).

\section{Standardization of spent broiler breeder hen chicken sausages in comparison with broilers}

\section{Procurement of raw materials}

On the next day of the slaughter, both spent broiler breeder hen and broiler chicken carcasses were deboned and meat was harvested. All subcutaneous fat and inter muscular fat was removed from the meat and used as the fat source.

The spice ingredients purchased from local market were cleaned thoroughly and dried in a hot air oven at $50^{\circ} \mathrm{C}$ per 60 minutes. The ingredients were ground separately in a Blender (Model: Panasonic MX-AC 3005) and sieved through a fine mesh. The powders were mixed in suitable proportions to obtain the spice mix and were stored at room temperature in air tight container for further use.

Other Non meat ingredients like sugar, salt, garlic, onions, binder were purchased from local super market. Onions and garlic were peeled off and made a fine paste in the ratio of 3:1 with help of mixer grinder.

\section{Preparation of sausages}

Both control and treatment chicken sausages were manufactured separately by using formulation as shown in Table 1. The steps in the preparation of sausages are shown inflow chart. Control sausages were formulated with broiler meat where as treatment sausages were formulated with spent broiler breeder hen meat. Meat and fat were separately subjected to thorough mincing a meat mincer (Continental CCE 89/189) through $6 \mathrm{~mm}$ diameter grinder plate to obtain a uniform mix and later through $4 \mathrm{~mm}$ diameter plate. Minced meat was chopped with salt, sugar, phosphate, fat, ice flakes, refine wheat flour, spices and condiments for $8 \mathrm{~min}$ in a bowl chopper (Schadfen 58452 written).

The treatment and control batters were stuffed into synthetic cellulose casings (SCC21) using horizontal sausage stuffer (SIRMAN - V15, Italy) and then linked, tied and cooked at $80^{\circ} \mathrm{C} / 40$ min in moist heat. The batches of both control and treatment cooked sausage samples, after cooling to ambient temperature were subjected to evaluate physic chemical, proximate and organoleptic parameters.

\section{Percent cooking yield}

Cooking yield was estimated by recording the difference between the pre and post cooking weights of meat sausages and expressed in percentage. 
$\%$ Cooking yield=

Weight of sample after cooking

---oright

Weight of sample before cooking

\section{Percent emulsion stability}

The Emulsion stability of the sample was determined by the method followed by Baliga and Madaiah (1970).

Twenty five grams of emulsion was taken in a sealed polythene bag and cooked at $80^{\circ} \mathrm{C}$ for 30 minutes in a water bath. Cookout was drained, cooked mass was cooled and weighed, and same was expressed as percent emulsion stability.

\section{Hardness}

\section{Penetration value}

The hardness of the product was measured in terms of penetration value (penetration value $\times 10-1 \mathrm{~mm}$ ) with the help of cone penetrometer as described by Dixon and Parekh (1979).

The product was placed on the platform of the cone penetrometer (ISI model, United scientific co. Madras) in such a way that the point of penetration was at least $2.5 \mathrm{~cm}$ away from the edge of the dish and the platform was so adjusted that the tip of the cone just touched the sample.

The cone assembly was allowed to descend in to the sample for exactly $10 \mathrm{sec}$. The distance through which the cone penetrated into the product was measured on the dial of the penetrometer.

\section{Proximate composition}

The per cent moisture, crude protein, crude fat and crude fibre were estimated as per the procedures outlined by AOAC (1994).

\section{Cholesterol}

Lipid extract was used as per the method described by Wybenga et al., (1970) as modified by Rajkumar et al., (2004). Lipid extract was prepared by taking one gram of the sample and adding $10 \mathrm{ml}$ freshly prepared 2:1 chloroform:Methanol solution and homogenized with laboratory model blender.

Homogenate was filtered using WhatmanNo.42 filter paper and to $5 \mathrm{ml}$ of filtrate equal quantity of distilled water was added, mixed and centrifuged at $3000 \mathrm{rpm}$ for 7 minutes.

Top layer (methanol) was removed by suction. Volume of the bottom (chloroform) layer having cholesterol was recorded. From this $25 \mu 1$ of the sample was pipette in a test tube and kept in a water bath $\left(100^{\circ} \mathrm{c}\right)$ for 2-3 min till it got dried.

To this $5 \mathrm{ml}$ of cholesterol reagent was added, mixed and kept in a boiling water bath for 90 seconds for colour development, the optical density of standard and test against blank was taken at $530 \mathrm{~nm}$. Total cholesterol $(\mathrm{mg} \%)$ was calculated as follows,

\section{Calculation}

$\frac{\text { O.D of the sample }}{\text { O.D of the standard }} \times \frac{\begin{array}{c}\text { Volume of the } \\ \text { Choloroform Layer }(\mathrm{ml})\end{array}}{\begin{array}{c}\text { Weight of the sample } \\ \text { taken }(\mathrm{g})\end{array}} \times 200$

\section{Sensory evaluation}

The chicken meat sausages thus prepared as per the standardized formulations were oven cooked separately and subjected to sensory evaluation on a 9 point hedonic scale by semitrained panalists. 


\section{Results and Discussion}

Physico-chemical parameters of spent broiler breeder and broiler meat

The physico-chemical parameters such as $\mathrm{pH}$, water holding capacity (WHC) protein fractionation: salt soluble protein extractability (SSPE), water soluble protein extractability (WSPE) and total protein extractability (TPE) of both spent broiler breeder hen and broiler chicken meat are presented in Table 2 .

The $\mathrm{pH}$ of meat from spent broiler breeder hen and broiler were $5.86 \pm 0.00$ and $5.85 \pm 0.009$ respectively. There was no significant difference in mean $\mathrm{pH}$ values between spent broiler breeder hen and broiler. The mean $\mathrm{pH}$ value of spent broiler breeder hen meat did not differ significantly with that of broiler meat. However spent broiler breeder hen meat recorded higher mean $\mathrm{pH}$ than broilers. This is in agreement with Ali et al., (2007), Bhaskar Reddy et al., (2016), Biswas et al., (2006), Boni et al., (2010), Khwunsiri et al., (2007) and Kumar et al., (2011).

The meat from spent broiler breeder hen had significantly higher WHC $(47.83 \pm 0.66)$ than that of broiler $(43.75 \pm 0.18)$. The SSPE of meat from spent broiler breeder hen and broiler were $9.64 \pm 0.04$ and 9.35 \pm 0.06 respectively. Higher $(\mathrm{P}<0.01) \quad$ SSPE was observed in spent broiler breeder hen when compared to the broiler. The WSPE of meat from spent broiler breeder hen $(5.26 \pm 0.05)$ and broiler $(5.15 \pm 0.04)$ did not differ significantly. The TPE of meat from spent broiler breeder hen and broiler were $14.84 \pm 0.10$ and $14.45 \pm 0.05$ respectively. Significantly $(\mathrm{P}<0.01)$ higher TPE was found to be observed in spent broiler breeder hen than broiler.

The spent broiler breeder hen meat was found to have significantly higher $(\mathrm{P}<0.01)$ water holding capacity, salt soluble protein extractability and total protein extractability when compared to broiler meat. Regarding Water soluble protein extractability did not differed significantly between spent broiler breeder hen and broiler meat. Similar trend is reported by Bhaskar Reddy et al., (2016), Kokoszynski et al., (2016), Kumar et al., (2011), Sutton et al., (1997) and Trindade et al., (2004).

\section{Standardization of methodology for preparation of sausages}

Two batches of chicken sausages were developed from spent broiler breeder hen and broiler meat after conducting preliminary trials for standardization of methodology and also compared the sausages made from meat of both spent broiler breeder hens and broilers based on physico-chemical, proximate and sensory evaluation.

\section{Physico-chemical properties}

The mean \pm SE values of physico chemical properties of sausages as influenced by type of meat are presented in Table 3.

\section{pH}

The mean values of $\mathrm{pH}$ of sausages prepared from spent broiler breeder hen and broiler were $6.24 \pm 0.01$ and $6.20 \pm 0.007$ respectively. Results revealed a significant $\quad(\mathrm{P}<0.05)$ difference in mean $\mathrm{pH}$ values between spent broiler breeder hen and broiler. The $\mathrm{pH}$ of meat and meat products is an important measure to estimate relative acidity or alkalinity which might indicate the potential storage life and quality of the meat and meat products. The mean $\mathrm{pH}$ of chicken sausages made from spent broiler breeder hen meat differed significantly $(\mathrm{P}<0.05)$ with that of broiler chicken sausages. Significantly $(\mathrm{P}<0.05)$ lower mean $\mathrm{pH}$ was observed in 
chicken sausages made from broiler meat. This might be due to variation in glycogen reserves, quality and quantity of glycolytic enzymes in two types of birds (Brahma et al., 1984). Similar findings are correlated with Bhattacharyya et al., (2007), Biswas et al., (2006), and Govind et al., (2013).

\section{Percent cooking yield}

The mean percent cooking yield of sausages prepared from spent broiler breeder hen and broiler were $87.38 \pm 0.41$ and $87.87 \pm 0.36$ respectively. Sausages made from spent broiler breeder hen chicken recorded significantly $(\mathrm{P}<0.05)$ higher percent cooking yield when compared to the sausages made from broiler. Cooking yield in meat and meat products is of utmost practical importance in meat industry. Sausages made from spent broiler breeder hen meat recorded significantly $(\mathrm{P}<0.05)$ higher percent cooking yield when compared to the sausages made from broiler. This might be due to comparatively lower water holding capacity of broiler muscles than spent broiler breeder muscles, resulting in a greater cooking loss and less stable emulsion (Joseph et al., 1992). Similar trend was reported by Bhattacharyya et al., (2007), Biswas et al., (2006), Govind et al., (2013), Kim, (2014) and Singh et al., (2002).

\section{Percent emulsion stability}

The mean of percent emulsion stability of chicken sausages prepared from spent broiler breeder hen and broiler were 87.07 \pm 0.15 and $87.56 \pm 0.18$ respectively. Significant $(\mathrm{P}<0.05)$ difference was observed in percent emulsion stability between spent broiler breeder hen and broiler chicken sausages. The emulsion stability was expressed as percent loss and hence lower the value, higher the stability of the product. Spent broiler breeder hen chicken recorded significantly $(\mathrm{P}<0.05)$ higher percent emulsion stability than broiler meat sausages. Emulsion stability indicates the ability of the emulsion to hold liquid at the time of performances of the emulsion and it is influenced by fat contents of the emulsion. Higher fat percentage of broiler sausage emulsion resulted in lower emulsion stability. Froning, (1972) reported that the duck patties had low emulsion stability due to higher fat content. Because of the highest stability of emulsion from spent broiler breeder hen meat which results in better retention of water and fat in meat matrix (Girish et al., 2003). These findings are in agreement with Biswas et al., (2006), Bhattacharyya et al., (2007) Ilayabharathi et al., (2012).

\section{Hardness}

The mean of percent hardness of sausages prepared from spent broiler breeder hen and broiler were $25.46 \pm 0.18$ and $26.12 \pm 0.09$ respectively. The mean percent hardness values of sausages was significantly $(\mathrm{P}<0.01)$ affected by type of meat. The mean hardness values of chicken sausages was significantly $(\mathrm{P}<0.01)$ affected by type of meat. Broiler meat sausages recorded higher mean penetration value than spent broiler breeder hen chicken sausages. It indicated that later were harder than the former. Spent broiler breeder hen meat produced significantly firmer sausages because of the tougher connective tissue in older birds than in broilers (Baker et al., 1970). Ilayabharathi et al., (2012) noticed higher shear force values for spent hen sausages when compared to broilers.

Added chicken fat at a level of $15 \%$ resulted in greater firmness and overall acceptability scores (Kondaiah and Ponda, 1987). Jin et al., (2007) found increased shear force values in sausages with increase in the level of spent hen meat incorporation. Kim (2014) concluded that the addition of spent hen meat resulted in increased hardness in sausages. 
Table.1 Formulation for chicken sausages

\begin{tabular}{|c|c|c|}
\hline S.no. & Ingredients & Quantity(\% weight basis) \\
\hline $\mathbf{1 .}$ & Chicken meat & 85 \\
\hline $\mathbf{2 .}$ & Chicken fat & 15 \\
\hline \multicolumn{3}{|c|}{ Total } \\
\hline $\mathbf{1 .}$ & Non meat ingredients \\
\hline $\mathbf{2 .}$ & Salt \\
\hline $\mathbf{3}$. & Sugar \\
\hline $\mathbf{4 .}$ & Poly phosphate \\
\hline $\mathbf{5 .}$ & Dry spice mix & 2 \\
\hline $\mathbf{6 .}$ & Wet condiment mix & 0.3 \\
\hline $\mathbf{7 .}$ & Binder(refined wheat flour) & 2 \\
\hline
\end{tabular}

Onion : Garlic paste ( $3: 1)$

Table.2 Mean \pm SE values of physico-chemical parameters of spent broiler breeder hen and broiler chicken meat

\begin{tabular}{|c|c|c|c|c|}
\hline S.No. & Parameter & SBBH & Broiler & t-value \\
\hline $\mathbf{1 .}$ & $\mathrm{pH}$ & $5.86 \pm 0.008$ & $5.85 \pm 0.009$ & 0.94 \\
\hline $\mathbf{2 .}$ & WHC & $47.83 \pm 0.66$ & $43.75 \pm 0.18$ & $5.907^{* *}$ \\
\hline $\mathbf{3 .}$ & $\begin{array}{c}\text { Salt soluble protein extractability } \\
\text { (SSPE) }\end{array}$ & $9.64 \pm 0.04$ & $9.35 \pm 0.06$ & $4.703^{* *}$ \\
\hline $\mathbf{4 .}$ & $\begin{array}{c}\text { Water soluble protein extractability } \\
\text { (WSPE) }\end{array}$ & $5.26 \pm 0.05$ & $5.15 \pm 0.04$ & 1.43 \\
\hline $\mathbf{5 .}$ & Total protein extractability (TPE) & $14.84 \pm 0.10$ & $14.45 \pm 0.05$ & $3.34^{* *}$ \\
\hline
\end{tabular}

"Significant at $0.01 \quad$ * Significant at $0.05 \quad$ SBBH- Spent broiler breeder hen

Table.3 Mean \pm SE values of physico-chemical parameters of spent broiler breeder hen and broiler meat sausages

\begin{tabular}{|c|c|c|c|c|}
\hline S.no. & Parameter & SBBH & Broiler & t-value \\
\hline $\mathbf{1 .}$ & pH & $6.24 \pm 0.01$ & $6.20 \pm 0.007$ & $2.54^{*}$ \\
\hline $\mathbf{2 .}$ & \% Cooking yield & $87.38 \pm 0.41$ & $87.87 \pm 0.36$ & $2.19^{*}$ \\
\hline $\mathbf{3 .}$ & \% Emulsion stability & $87.07 \pm 0.15$ & $87.56 \pm 0.18$ & $2.07^{*}$ \\
\hline $\mathbf{4 .}$ & Hardness $(\mathrm{mm})$ & $25.46 \pm 0.18$ & $26.12 \pm 0.09$ & $3.17^{* *}$ \\
\hline $\mathbf{5 .}$ & Cholesterol $(\mathrm{mg})$ & $81.45 \pm 0.08$ & $83.09 \pm 0.04$ & $12.02^{* *}$ \\
\hline
\end{tabular}

"Significant at $0.01 \quad$ "Significant at 0.05 SBBH-Spent broiler breeder hen 
Table.4 Mean \pm SE values of proximate composition of chicken sausages as influenced by type of meat

\begin{tabular}{|c|c|c|c|c|}
\hline S.no. & Parameter & SBBH & Broiler & t-value \\
\hline $\mathbf{1 .}$ & \% Moisture & $67.14 \pm 0.05$ & $68.17 \pm 0.11$ & $8.23^{* *}$ \\
\hline 2. & \% Crude protein & $18.44 \pm 0.05$ & $17.32 \pm 0.07$ & $12.02^{* *}$ \\
\hline 3. & \% Crude fat & $10.64 \pm 0.08$ & $11.38 \pm 0.07$ & $2.149^{*}$ \\
\hline $\mathbf{4 .}$ & \% Total ash & $1.51 \pm 0.03$ & $1.43 \pm 0.01$ & $6.68^{* *}$ \\
\hline $\mathbf{5 .}$ & \% Crude fiber & $0.66 \pm 0.007$ & $0.56 \pm 0.018$ & $5.108^{* *}$ \\
\hline
\end{tabular}

"Significant at $0.01 \quad$ "Significant at $0.05 \quad$ SBBH-Spent broiler breeder hen

Table.5 Mean \pm SE values of sensory evaluation of chicken sausages as influenced by type of meat

\begin{tabular}{|c|c|c|c|c|}
\hline S.no. & Parameter & SBBH & Broiler & t-value \\
\hline $\mathbf{1 .}$ & Appearance & $7.93 \pm 0.15$ & $8.04 \pm 0.14$ & 0.493 \\
\hline $\mathbf{2 .}$ & Flavour & $8.31 \pm 0.14$ & $8.00 \pm 0.18$ & 0.172 \\
\hline $\mathbf{3 .}$ & Juiciness & $7.75 \pm 0.16$ & $7.93 \pm 0.18$ & 0.753 \\
\hline $\mathbf{4 .}$ & Tenderness & $7.91 \pm 0.15$ & $7.98 \pm 0.16$ & 0.270 \\
\hline $\mathbf{5 .}$ & Overall acceptability & $7.83 \pm 0.14$ & $7.88 \pm 0.17$ & 0.228 \\
\hline
\end{tabular}

"Significant at $0.01 \quad$ *Significant at $0.05 \quad$ SBBH-Spent broiler breeder hen

Chart.1 Proximate composition of chicken sausages as influenced by type of meat

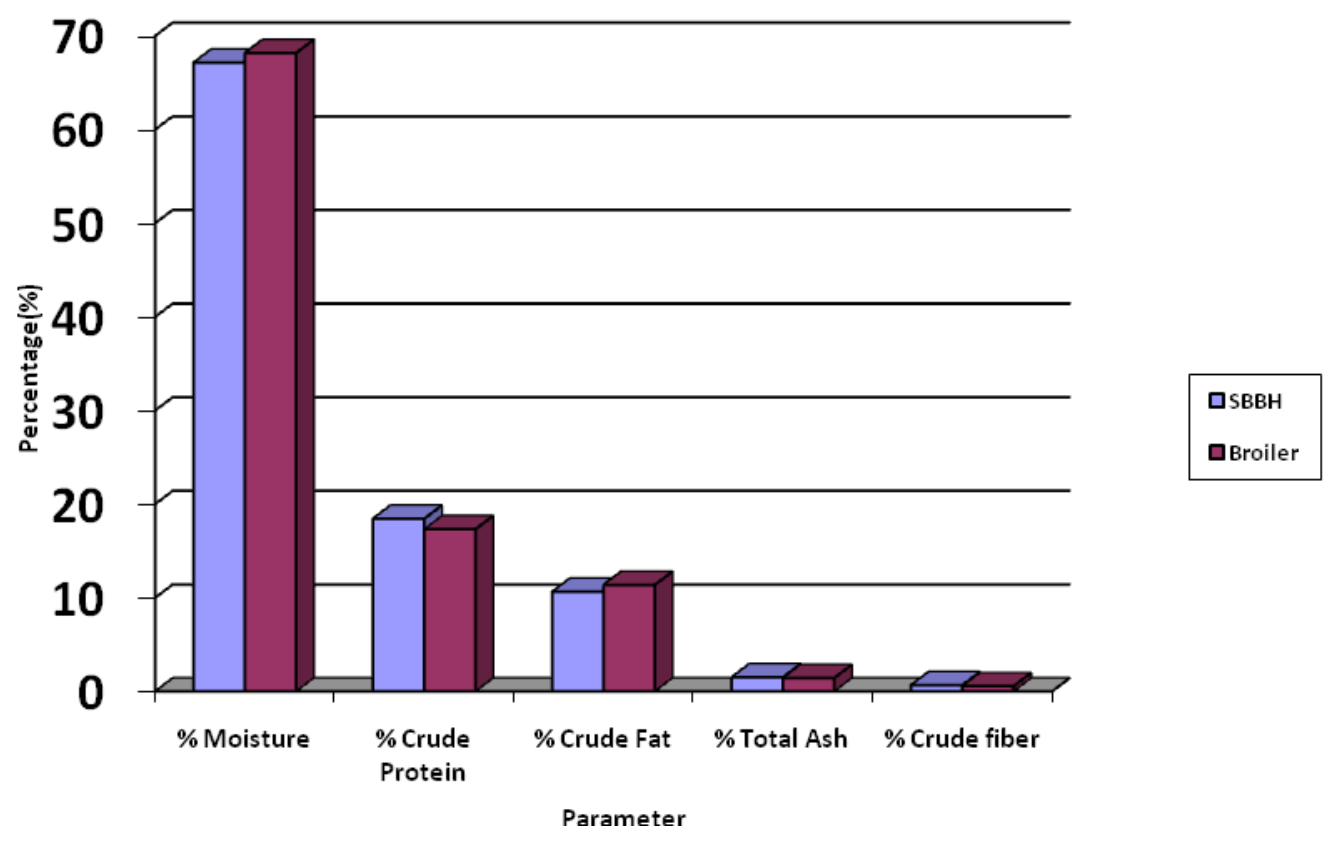




\section{Cholesterol}

The mean of percent cholesterol of sausages prepared from spent broiler breeder hen and broiler were $81.45 \pm 0.08$ and $83.09 \pm 0.04$ respectively. Sausages made from spent broiler breeder hen chicken recorded significantly $(\mathrm{P}<0.01)$ lower cholesterol values when compared to the sausages made from broiler. Sausages made from Spent broiler breeder hen meat recorded significantly $(\mathrm{P}<0.01)$ lower cholesterol values when compared to the sausages made from broiler. This may be because of lower fat content of spent broiler breeder meat than broilers. These findings are in agreement with Ang and Hamm (1982), Jin et al., (2007) and Trindade et al., (2004).

\section{Proximate composition of sausages made from spent broiler breeder hen and broiler}

The mean \pm SE values of proximate composition of sausages as influenced by type of meat are presented in Table 4. Proximate composition of chicken sausages as influenced by type of meat is represented in Chart No.1.

The mean \pm SE values of percent moisture for sausages prepared from spent broiler breeder hen and broiler were $67.14 \pm 0.05$ and $68.17 \pm 0.11$ respectively. The mean $\pm \mathrm{SE}$ values of percent crude protein for sausages made from spent broiler breeder hen and broiler were $18.44 \pm 0.05$ and $17.32 \pm 0.07$ respectively. The mean \pm SE values of percent crude fat for sausages made from spent broiler breeder hen and broiler were $10.69 \pm 0.08$ and $11.38 \pm 0.07$ respectively. The mean $\pm \mathrm{SE}$ values of percent total ash for sausages made from spent broiler breeder hen and broiler meat were $1.51 \pm 0.03$ and $1.43 \pm 0.01$ respectively. The mean \pm SE values of percent crude fiber for sausages made from spent broiler breeder hen and broiler were $0.66 \pm 0.007$ and $0.56 \pm 0.018$ respectively.
Chicken sausages made from spent broiler breeder hen meat found to have significantly $(\mathrm{P}<0.01)$ higher percentages of crude protein, crude fiber, total ash and significantly $(\mathrm{P}<0.01)$ lower percentages of moisture, crude fat when compared to the broiler meat sausages. Protein and fat content of two groups of sausages are within the permissible limits of BIS, which specified that the maximum fat content of sausage should not be above $20 \%$. The range of values of crude fiber content in sausages can be attributed to flour, condiments and spices (Biswas et al., 2011). These findings are correlated with Bhattacharya et al., (2007), Ilayabharathi et al., (2012), Jin et al., (2007), Kim, (2014) and Suradkar et al., (2013).

\section{Sensory evaluation of spent broiler breeder hen and broiler chicken sausages}

The mean \pm SE values of sensory parameters like appearance, flavor, juiciness, tenderness and overall acceptability of chicken sausages as influenced by type of meat are presented in Table 5 .

The mean \pm SE values of appearance for sausages made from spent broiler breeder hen and broiler were $7.93 \pm 0.15$ and $8.04 \pm 0.14$ respectively. The mean \pm SE values of flavour for sausages made from spent broiler breeder hen and broiler were $8.31 \pm 0.14$ and $8.00 \pm 0.18$ respectively. The mean \pm SE values of juiciness for sausages made from spent broiler breeder hen and broiler were $7.75 \pm 0.16$ and $7.93 \pm 0.18$ respectively. The mean $\pm \mathrm{SE}$ values of tenderness for sausages made from spent broiler breeder hen and broiler were 7.91 \pm 0.15 and $7.98 \pm 0.16$ respectively. The mean $\pm \mathrm{SE}$ values of overall acceptability for sausages made from spent broiler breeder hen and broiler were $7.83 \pm 0.14$ and $7.88 \pm 0.17$ respectively. Sausages made from broiler meat recorded uniformly higher scores for all sensory parameters except flavor when 
compared to the spent broiler breeder hen meat sausages; however the difference was not statistically significant. Scores of all sensory parameters for two groups of sausages were in the range of 8.31-7.75 (Good acceptability) which indicates acceptability of the chicken sausages. Mean sensory scores of chicken sausages were not significantly $(\mathrm{P}<0.05)$ affected by type of meat. However, chicken sausages made from broiler meat scored uniformly higher scores for all sensory parameters except flavour than spent broiler breeder hen sausages. Better scores for broiler nuggets might be attributed to more tender meat and less fibrous meat tissues as compared to spent hen meat (Wenham et al., 1973). Present findings are in close agreement with those of Biswas et al., (2006). Scores of all sensory parameters for two groups of sausages were in the range of $7.75-8.31$ (Good acceptability) which indicates acceptability of the chicken sausages. Similar trend is reported by Bhattacharyya et al., (2007) in spent duck sausages, Lengkey and Lobo (2016) in comparative study of chicken and rabbit low fat sausages, Pawar et al., (2011) in spent chicken patties and Sreenivasa Rao et al., (2011) in spent hen chicken sausages. Sausages made from spent broiler breeder hen meat had significantly superior scores in physico chemical and proximate analysis than sausages made from broiler meat and also noticed no significant difference in sensory scores between two groups of sausages. Hence, spent broiler breeder hen meat can be used for development of low fat chicken sausages fortified with vegetable oil seed paste as partial fat replacer.

\section{References}

Ajuyah, A. O., Hardin, T. R., Cheung, K and Sim, J.S. (1992). Yield, lipid, cholesterol and fatty acid composition of spent hens fed full-fat oil seeds and fish meal diets. Journal of Food Science., 57: 338-341.

Ali, Md., Ho Kang, S.G., Yang, H.S., Jeong,
J.Y., Hwang, Y.H., Park,G.B and Joo, S.T. (2007). A Comparison of Meat Characteristics between Duck and Chicken Breast. Asian-Australasian Journal of Animal Sciences.,20(6): 1002-1006.

Ang, C. Y.W and Hamm, D. (1982). Proximate analyses, selected vitamins and minerals and cholesterol content of mechanically deboned and hand deboned broiler parts. Journal of Food Science., 47(3):885 888.

(AOAC), Association of Official Analytical Chemistry. (1994). Official methods of analysis of the Association of Official Analytical Chemists, Vols. I \& II, Association of Analytical Chemists, Arlington: 1298.

Baker, R. C., Darfler, J. M and Vadehra, D. V. (1970). Effect of type, age and freezing ofpoultry meat before processing on the quality of chicken frankfurters. Poultry Science 49: 747-751.

Balinga, B.R and Madaiah, N. (1970). Quality of sausage emulsion prepared from mutton. Journal of Food Science., 35: 383-385

Bhattacharya, D., Sinhamahapatra, $M$ and Biswas, S. (2007). Preparation of sausage from spent duck- an acceptability study. International journal of food science and technology., 42:2429.

Bhaskar Reddy, G.V., Naga Mallika, E., Obula Reddy, B., Azad, S.A.K and Maheswara Reddy, D. (2016). Comparison on meat quality characteristics of spent Breeder, layer and broiler birds. International Journal of Science, Environment and Technology., 5 (4): 2590- 2595.

Biswas, S., Apurb, C and Sanji, S. (2006). Comparison among the qualities of patties prepared from chicken broiler, spent hen and duck meats. The Journal of Poultry Science.,.3:180-186.

Boni, I., Nurul, $\mathrm{H}$ and Noryati, I. (2010).Comparison of meat quality characteristics between young and spent quails. International Food Research Journal., 17: 661-666 
Brahma, M.L., Narayana Rao, P.L.N and Nath, D. R. (1984). Comparative study of certain qualitative characteristics of duck and hen meat: $\mathrm{pH}$, water holding capacity and palatability characteristics of meat. Indian Veterinary Journal., 61:978-983.

Dixon, B.D and Parekh, J.V. (1979). Use of the cone penetrometer for testing the firmness of butter. Journal of Food Science., 10:421-434.

Froning, C. W. (1972). Effect of skin content on emulsifying and colour characteristics of mechanically deboned back meat. Poultry Sci., 51: 1809.

Girish, P.S., Sanyal, M.K., Keshri, R.C and Anjaneyulu, A.S.R (2003). Quality of chicken patties incorporated with whey protein concentrate. Journal of Meat Science., 1(1):27-29.

Govind, V., Prabhakar, K., Eswara Rao, B and Naga Mallika, E. (2013).Eating quality and physico-chemical properties of Fresh emu meat sausages prepared in comparison with Broiler and spent hen meat sausages with oat flour andCorn flour. International Journal of Food, Agriculture and Veterinary Sciences., 3 (1): 247-253.

Grabowski, W. (2004). Slaughter material. In: Meat and Poultry Products. Technology. Higiene. Quality. (In Polish) WN-T Warszawa. Pp. 16-39.

Ilayabharathi, D., Sheriff, F. R and Raj Manohar, G. (2012). Shelf-life of spent chicken sausage and Its organoleptic qualities. Tamilnadu J. Veterinary \& Animal Science., 8 (2) :60-67.

Jay, J.M. (1964). Beef microbial quality determined by extract release volume (ERV). Food Technol., 18:1633.

Jin, S.K., Kim, I.S., Jung, H. J., Kim, D. H., Choi, Y. J and Hur, S. J. (2007). The Development of Sausage Including Meat from Spent Laying Hen Surimi. Poultry Science., 86:2676-2684.

Joo, S. T., Kauffman, R. G., Kim, B. C and Park, G. B. (1999). The relationship of sarcoplasmic and myofibrillar protein solubility to color and water holding capacity in porcinelongis simus muscle. Meat Sci., 52:291-297.

Kang, C. K and Rice, E.E.J. (1970). Degradation of various meat fraction by tenderizing enzyme. Food Sci., 35:563.

Khwunsiri, C.H., Wattanachant, $S$ and Siripongvutikorn. S. (2007). Chemical an physical properties of raw and cooked spent hen, broiler and Thai indigenous chicken muscles in mixed herbs acidified soup (Tum Yum). Journal of Food Technology. 5(2) 180-186.

Kokoszyński, D., Bernacki, Z., Stęczny, K., Saleh, M,. Wasilewski, P. D., Kotowicz, M., Wasilewski, R., Biegniewska, $\mathrm{M}$ and Karolin, A. (2016). Comparison of carcass composition, physicochemical and sensory traits ofmeat from spent broiler breeders with broilers. Europ. Poult. $\quad$ Sci: $\quad 80 . \quad$ (DOI: 10.1399/eps.2016.131).

Komiyama, C.M., Mendes, A.A, Sanfelice, C., Canizares, M. C., Roca, R. O., Takahashi, S.E., Rodriguez, L. Canizares, G. I. L, Paz, I. C. L. A and Cordoso, K. F.G. (2010). Physical, chemical and sensorial breast meat quality of spenthens. Ciencia Rural, Santa Maria., 40: 1623-1629.

Kondaiah, N. (1993). Products from spent hen. Poultry International., 49: 46-47.

Kondaiah, N and Panda, B. (1987). Effect of hot and cold boning of spent hens on carcass components and functional properties of the frozen meat. International Journal of Food Science and Technology., 22: 413416.

Kumar, V., Biswas, A.K., Chatli, M.K and Sahoo, J. (2011). Effect of banana and soybean hull flours on vacuum packaged chicken nuggets during refrigeration storage. International Journal Food Science and Technology, 46(1): 122129.

Kim, Y.J. (2014). The Study on the Quality of Sausage Manufactured with Different Mixture Ratios of Spent Laying Hen and Pork Meat. Korean J. Poult. Sci., 41(4): 
271-277.

Lengkey, H.A.W and Lobo, B.R. (2016). Physico-chemical and microbiological Characteristics, sensory quality and acceptability of native chicken and rabbit sausage produced with corn oil, margarine and beef fat. Macedonian Veterinary Review., 39 (2): i-vii.

Lyons, J.J. (2001) Spent hen utilization. In: Midwest Poultry Federation Egg Production Workshop, St. Paul.

Lyon, C. E., Lyon, B. G and Savage, E. M. (2003). Effect of postchill deboning time on the texture profile of broiler breeder hen breast meat. J. Appl. Poult. Res., 12:348-355.

Pawar, V.D, Karthikeyan, B., Zanjad, P. N., Machewad, G. M and Chappalwar, A.M. (2011). Process optimization for chicken patties manufactured with a combination of spent hen and rabbit meat. Journal of food quality. 34: 236-244.

Rajkumar, V., Agnihotri, M. K and Sharma, N. (2004). Quality and Shelf-life of Vacuum and Aerobic Packed Chevon Patties under Refrigeration. Asian Australasian Journal of Animal Sciences., 17(4): 548-553.

Singh, V. P., Sayal, M.K., Dubey, P. C. (2002). Quality of chicken snack containing broiler spent hen meat, rice flour and sodium caseinate. J. Food Sci. Technol., 39(4), 442-444.

Sreenivasa Rao, G., Moorthy, P. R.S and Jagadeesh Babu, A. (2011). Process optimization for the development of chicken sausages with spent chicken meat and offal's. Tamilnadu J. Veterinary \& Animal Sciences., 7 (2): 64-70.
Suradkar, U. S., Bumla, N. A., Maria, A., Sofi, A.S and Wani, S.A. (2013). Comparative Quality of Chicken Nuggets Prepared from Broiler, Spent Hen and Combination Meats. International Journal of Food Nutrition and Safety, 3(3): 119-126.

Sutton, D. S., Ellis, M., Lan, Y., Mc Keith, F. K and Wilson, E. R. (1997). Influence of slaughter weight and stress gene genotype on the water-holding capacity and protein gel characteristics of three porcine muscles. Meat Science, 46: 173180.

Trindade, M. A., De Felíci, P. E and Contreras Castillo, C. J. (2004). Mechanically separated meat of broiler breeder and white layer spent hens. Scientia Agricola (Piracicaba, Brazil)., 61: 234-239.

Voller-Reasonover, L., Han, I. Y., Acton, J. C., Titus, T. C., Bridges, W. C and Dawson, P. L. (1997). High Temperature processing effects on the properties of fowl meat gels. Poultry Science., 76: 774-779.

Wardlaw, F. B., McCaskill, L. H and Acton, J. C. (1973). Effects of postmortem muscle changes on poultry meat loaf properties. J. Food Sci., 38: 421-423.

Wenham, L. M., Fairbain, K and Mdeod, W. (1973). Eating quality of mutton compared with lambs and its relationship to freezing practices. J. Anim. Sci., 36: 1081.

Wybenga, D. R., Pileggi, V., Dirstine, J., John Di Giorgio P. H. (1970). Direct Manual Determination of Serum Total Cholesterol with a Single Stable Reagent. Clinical chemistry., 16(12): 980-984.

\section{How to cite this article:}

Indumathi, J., M. Shashikumar, G. Vijaya bhaskar Reddy, A. Jagadeesh Babu and Gnana Prakash, M. 2019. Utilization of Spent Broiler Breeder Hen Meat to Develop Value Added Sausages. Int.J.Curr.Microbiol.App.Sci. 8(12): 754-765.

doi: https://doi.org/10.20546/ijcmas.2019.812.099 